\title{
TAXATION OF PROPERTY TRANSFERS IN MARRIAGE SETTLEMENTS IN CONNECTION WITH DIVORCE
}

\author{
By Georae L. HUDSPETH*
}

When property is transferred from one spouse to another in connection with a divorce a difficult question may arise as to whether this contitutes a taxable gift nnder the federal gift tax. ${ }^{1}$ The first factor to keep in mind is the consideration upon which the settlement is based.

\section{Support and Maintenance Rights}

With the exception of several decisious in the Second Circuit, which the Treasury has announced that it will not follow, ${ }^{2}$ it seems well settled that a transfer from the husband to the wife of $\$ X$ in cash or a like value in property, either in lump sum or over a period of time, for release of the wife's right to support and maintenance will not be taxed as a gift. ${ }^{3}$ This is true, of course, only so long as the value of the transfer does not exceed the value of the "right" to support and maintenance, based upon acceptable actuarial tables. The elements to be considered in determination of the value of the support rights are "the amount of the husband's annual income, the extent of his assets, the life expect1950.

* 3rd jear law stuđent, Duke University; B.S. Texas Christian University,

1 Though consideration of income and estate taxes are likewise of importance in these settlements, the comment is limited to the question of gift taxes.

'See E. T. 19, 1946.2 CoMr. BuLL. 166, wherein it is stated: "The cases of Ifeyer's Estate v. Helvering, [110 F. 2d. 367 (2nd Cir., 1940), cert denied 310 U. S. 651 (1940)] and Helvering v. United States Trust Co. et al., [111 F.2d 576 (2nd Cir., 1940)] will no longer be followed to the extent that they hold that the right of a divorced wife to support from a former husband during the joint lives of the parties is a marital right in his property or estate."

3 Commissioner v. Converse, 163 F. 2d 131 (2d Cir. 1947). In E. T. 19, supra note 2, it is stated: "Under a decree of divorce or legal separation a husband's duty to support a divorced wife (alimony) customarily lasts only during the joint lives of the parties or until the divoreed wife remarries ...

"The construction spelled out in section 812(b) [of the I. R. C.], . . governs the interpretation of the phrase 'adequate and full consideration in money or money's worth' as that phrase is used in section 1002 of the Internal Revenue Code. .. Sec. 812 (b), however, makes no specific reference to support rights. It is the view of the Bureau that the surrender of snpport rights is not one of the 'other marital rights' referred to in the section." 
ancies of the parties and the probability of the wife's remarriage. . .'"4

\section{Other Marital Rights}

There is more uncertainty concerning the taxation of transfers made in exchange for a release of the spouse's right of dower and curtesy or their statutory subsitutes. Section 1002 of the Internal Revenue Code, dealing with a transfer for less than adequate and full consideration, provides that any transfer will be taxed to the extent that the "value of the property [transferred] exceed [s] the value of the consideration" for the transfer." This section does not give any indication that a relcase of dower or curtesy rights will not be full and adequate consideration in money or money's worth. The courts have, however, held that such a release is not an adequate and full consideration. ${ }^{6}$ This conclusion has been reached by introducing part of the estate tax provisions into the gift tax statute. ${ }^{7}$ The interpolation has been justified

E. T. 19, 1946-2 Cour. BurL. 166 at 169.

- 26 USCA $\$ 1002$. "Transfer for less than adequate and full consideration. Where property is transferred for less than an adequate and full consideration in money or money's worth, then the amount by which the value of the property exceeded the value of the consideration shall, for the purpose of the tax imposed by this ehapter, be deemed a gift, and shall be included in computing the amount of gifts made during the calendar year." (Italics added.) See, also, Treas. REG. 108, $\$ 86.8$.

- This rule seems to have been settled by the eases of Commissioner $v$. Wemyss, 324 U. S. 303 (1945), Merrill v. Fahs, 324 U. S. 308 (1945), and Commissioner v. Bristol, 121 F.2d 129 (1st Cir., 1941). Though all thoso cases dealt with ante-nuptial agreements, the case of Harris $\nabla$. Commissionor, 340 U. S. 106 (1950), intimates that the same rule will be applicable in postnuptial agreements.

26 USCA $\$ 812$, relating to the net estato and showing deductions, exemptions, ete, which may be made, states, in part, at par. (b)(4): "For the purposes of this subchapter, a relinquishment or promised relinquishment of dower, curtesy, or of a statutory estate created in lieu of dower or curtesy, or of other marital rights in the decedent's proporty or estate, shall not bo considered to any extent a consideration in 'money or money's worth.' " This is one of the portions of the estate tax which has been read into the gift tax.

Mr. Justice Frankfurter in Merrill v. Fahs, supra note 6 at p. 311, explains the interrelated portions of the estate and gift tax as follows: "Tho guiding light is what was said in Estate of Sanford v. Commissioner, 308 U. S. $39,44[1939], \ldots$ : 'The gift tax was supplementary to the ostate tax. The two are in pari materia and must bo construed together.' The phraso ... of ... transfers for other than 'an adequate and full considoration in money or money's worth'-came into the gift tax by way of estate tax provisions. ... 
on the ground that the gift tax was passed to prevent the depletion of an estate prior to the death of the owner of the estate, and that without the inclusion of that portion of the estate tax provisions into the gift tax law a large source of revenue would be lost to the Treasury, since dower and curtesy and their statutory substitutes are explicitly taxed under the estate tax..$^{8}$

\section{What Effect Does a Decree of Court Have Upon Taxability or Non-Taxability of Transfers in Settlement of Marital Rights Other Than for Support and Maintenance?}

If the court decree merely compels a transfer of property to the spouse in settlement of support and maintenance rights, there will apparently be no gift tax imposed. ${ }^{9}$ If the court decree orders

"In 1924 Congress limited deductible claims against an estate to those supported by 'a fair consideration in money or money's worth.' ... Similar language was used in the gift tax, first imposed by the 1924 Act, by providing, 'Where property is sold or exchanged for less than a fair consideration in money or money's worth' the excess shall be deemed a gift. . . .

"When the gift tas was re-enacted in the 1932 Revenue Act, the restrictive phrase 'adequate and full consideration' as found in the estate tax was taken over by the draftsman. ...

"To be sure, in the 1932 Act Congress specifically provided that relinquishment of marital rights for purposes of the estate tax shall not constitute 'consideration in money or money's worth.' .. .

"We believe that there is every reason for giving the same words in the gift tax the same reading ... [T]o interpret the same phrases in the two taxes concerning the same subject matter in different ways when obvious reasons do not compel divergent treatment is to introduce another and needless complexity into this already irksome situation. To hold otherwise would encourage tax avoidance."

8 "An important, if not the main, purpose of the gift tax was to prevent or compensate for aroidance of death taxes by taxing the gifts of property inter vivos, which, but for the gifts, would be subject to the tax laid upon transfers at death." Estate of Sanford v. Commissioner, 308 U. S. 39, 44 (1939), rehearing denied 308 U. S. 637 (1939). "The tax upon gifts is closely related both in structure and in purpose to the tax upon those transfers that take effect at death. What is paid upon the one is in certain circumstances a credit to be applied in reduction of what will be due upon the other .... The gift... [and] ...the estate tax... are plainly in pari materia." Burnet $\nabla$. Guggenheim, 288 U. S. 280, 286 (1933). See 26 USCA 812, supra note 7.

In his dissent in Merrill $v$. Fahs, supra note 6 at p. 315, Mr. Justice Reed states: "It seems to us clear that with the judicial history of the difficulties in estate and gift taxes as to the transfer of marital rights when Congress expressly provided that relinquishment of dower, curtesy or other statutory estate was not 'consideration' for estate tax purposes and left the gift tax provision without such a limitation, it intended that these rights be accorded a different treatment under these sections."

- See supra note 3. 
the transfer to be made in settlement of a release of dower or curtesy rights, the question becomes more difficult. Where the property settlement evolves from an actual litigation before the court no gift tax will be incurred.10

Harris $v$. Commissioner ${ }^{11}$ further complicates the gift tax problems in connection with divorce settlements. In the Harris case both the husband and wife made eertain transfers of property, but the value of that transferred to the husband exceeded that received by the wife in the amount of $\$ 107,500$. The settlement agreement contained a provision that "the Recitals or covenants herein" shall not "become binding upon either party nnless a decree of absolute divorce between the parties shall be entered in the pending Nevada action."12 Thus the transfers were conditioned on a divorce being granted. A divorce decree was handed down by the appropriate Nevada court and the transfer was effectuated. The Nevada court had decreed that: "It is ordered that said agreement and trust agreements forming a part thereof shall survive this decree."13 The actual agreement of the parties contained a stipulation that the covenants therein were to survive any decree of the court. ${ }^{14}$

The Circuit Court of Appeals, by L. Hand, J., had ruled that the transfers were taxable under the gift tax. ${ }^{15}$ The reasoning given by Judge Hand was that since the transfers were " 'founded' upon both" a promise or agreement and the judicial decree, "the parties chose to submit themselves to two sanctions-contempt under the divorce court and execution under the contract. The payments were therefore subject to the gift tax."18 The Supreme Court, however, refused to accept this point of view. Instead, the Supreme Court held that the transfers were not founded upon a promise or agreement, but founded upon the decree of the Nevada court, and therefore, held them to be non-taxable.

The Harris case indicates that where the obligation for the transfer arises from the divorce decree there will be no gift tax,

${ }^{10}$ Converse v. Commissioner, supra note 3.

11340 U. S. 106 (1950). An excellent comment on the Harris case and its consequences will be found in an article by Pedrick, The Gift Tax Jurisdiotion of the Divorce Court, 46 In工. L. REv. 177 (195I).

12340 U. S. 106 at 110 .

13 Id. at 111.

14 Ibid.

${ }^{15}$ Harris v. Commissioner, 178 F.2d 861 (2d. Cir., 1949).

${ }^{16} I \pi$. at 865 . 
because, even though there is no adequate and full consideration for the transfer, there is no need for full and adequate consideration when the source of the transfer is the decree of court and not a promise or agreement. "In each case it is the decree that creates the rights and duties; and a decree is not a "promises or agreement' in any sense-popular or statutory."117 Therefore, the local statutes of states allowing property settlements in divorce cases are of no controlling force until the decree of the court is issued, because, "The decree, not the agreement submitted to the court, would fix the rights and obligations of the parties." 18

It seems settled that a purely voluntary agreement, not incorporated into any divorce decree, to transfer property in consideration of a release of dower or curtesy would be a taxable gift. This appears true from the fact that Section 812 (b) (4) of the estate tax has, in part, been read into the gift tax. ${ }^{19}$

\section{When Obligations Are Imposed by Decree of Court and When Imposed by Agreement of the Parties}

As intimated by Harris, if the transfer is pursuant to a decree of court, there need be no consideration present for the transfer to bc tax free. However, the first case decided by the tax court, MCcMurty $v$. Commissioner, ${ }^{20}$ after the Harris case relating to a release of marital rights seems to be contrary to the Harris principle. McII urty was very similar to Harris, except that in McMurty the settlement agreements were not conditioned upon a decree of divorce. The tax court ruled that the amount of the transfer in excess of the value of support rights was taxable, and distinguished Harris on the tenuous ground that that decision "was hinged on the fact that the effective operation of the property settlement was by its terms subject to a condition precedent, that there be an entry of divorce decree."2I This distinction appears tenuous since the

17340 U. S. at 110.

Id. at 111. "It is 'the transfer' of the property with which the gift tax statute is concerned, not the sanctions which the law supplies to enforce transfers. If 'the transfer' of marital rights in property is effected by the parties, it is pursuant to a 'promise or agreement' in the meaning of the statute. If 'the transfer' is effected by court decree, no 'promise or agreement' of the parties is the operative fact."

Cf. Krause v. Yoke, 89 F. Supp. 91 (N. D. W. Va., 1950).

${ }^{18} 340$ U. S. at 110 .

${ }^{20}$ See supra note 7.

${ }^{20} 16$ T. C. 168 (1951).

${ }^{21} \mathrm{Id}$. at 176 . 
Harris decision does not, by its language, seem to rest upon the fact that the transfers were subject to a condition precedent.

There were two property settlement agreements in the McMurty case. The first divorce decree made no reference at all to the agreement of the parties and made no provision for alimony; the divoree being obtained in Maine. No criticism may be made of the taxability of the transfer in settlement of that divorce, since the transfer, in a case where the court neither ratifies, adopts, or incorporates the agreement nor makes any distribution of the property in its decree, would be taxable on the ground that the transfer was made solely pursuant to a "promise or agreement." However, the second divorce decree was obtained in Nevada, the same jurisdiction in which the Harris case was decided, and the Nevada court decreed that, "It is further ordered, adjudged and decreed that the said agreement entered into between the plaintiff and the defendant on May 21, 1942, be, and the same hereby is, approved."22 The McMurty case, therefore, seems to be wrong insofar as it holds, in contra-distinction to the Harris case, that all transfers in both divorce settlements were taxable, except for support rights, even though part of the transfers made were approved and incorporated as part of the decree of divorce.

\section{Significance of the Harris Case}

Does the.Harris case mean that if a transfer is made pursuant to a decree of court, that decree alone is sufficient to keep the transfer from being taxable? A brief comparison of the Harris case with that of Hooker $v$. Commissioner ${ }^{23}$ indicates a negative answer. In the Hooker case the taxpayer had agreed, as part of a divoree settlement with his wife, to set up a trust for the benefit of their children. The divorce decree had ratified and adopted the agreement. Later, the wife had to get a decree of specific performance to force the husband to make the transfer. The transfer, except for the amount which the taxpayer was obligated to contribute for support of the children, was held to be taxable. It seems, therefore, that a transfer pursuant to a court decree which is not supported by an adequatesand full consideration will be a taxable gift unless the deeree of the court enforces an obligation which

${ }^{22} I d$. at 173 .

${ }_{23} 174$ F.2d 863 (5th Cir., 1949). See also Stowoska v. Pedrick, -F.Supp.-, (S.D.N.Y., June 30, 1952); Cf. Commissioner v. Greene, 119 F.2d 383 (9th Cir., 1941). 
arises apart from a promise or agreement. The father in the Hooker case could not have been placed under a legal obligation by a court to make the transfer in excess of support rights had it not been for the antecedent voluntary promise to that effect. A court may force a father to transfer funds to his son for support, but it cannot compel a vountary gift over and above the amount requisite for that purpose.

The Harris case differs from the Hooker case in that the court in the Harris case had power to order equitable interspousal settlements of property in divorce actions, regardless of any promise or agreement between the spouses. The decree in the Hooker case did not create the obligation for the transfer; it merely put judicial sanction behind the agreement of the parties and enforced the preexisting obligation created by their contract. The obligation to make a transfer was created by the decree in the Harris case. The court there was free to order any distribution which it deemed equitable. ${ }^{24}$ It could have completely disregarded the contract between the spouses. It chose to incorporate the agreement in its decree because the agreement coincided with the court's judgment as to what constituted a just and equitable settlement. However, the court decree in the Harris case went beyond mere enforcement of the pre-existing obligation to transfer the property. This obligation was expressed in terms of the agreement, but it originated in the decree of the court, not in the contractual arrangement between the spouses.

The situation in the Harris case is analogous to a transfer to settle a tort liability, which is not a taxable gift because the obliga-

24 In the Harris case, 340 U. S. at 109, a footnote reference was made by the Supreme Court stating: "At the time of the divorce Nevada Compiled Laws (Supp. 1931-41) $\$ 9463$ provided: 'In granting a divorce, the court may award such alimony to the wife and shall make such disposition of the community and separate property of the parties as shall appear just and equitable, having regard to the respective merits of the parties and to the condition in which they will be left by such divorce, and to the party through whom the property was acquired, and to the burden, if any, imposed upon it for the benefit of the children." (Italics added.)

Tho above law has since been changed slightly. The NEvADA LAWs, 1943, c. 91, p. 117 , amended the statute and the words "and separate" as appearing above have been eliminated.

"Thirty jurisdictions have statutes [varying] ... from provisions desig nating that a decree for alimony and the support of children constitutes or may be made a lien upon property, to statutes giving to the court complete discretion as to the disposition of all of the parties' property." 2 VERNIER, AMIERICAN FAXALT LAW, \$96 (1932 ed.). 
tion to make the transfer is imposed by law apart from any promise or agreement. Presumably in such a situation a voluntary settlement out of court will not be a taxable gift. ${ }^{25}$ The test of taxability is not whether the transfer is made pursuant to a judicial judgment or a voluntary settlement, but whether it derives its ultimate sanction from a promise or agreement. A voluntary settlement to discharge a tort liability is not a taxable gift because it represents merely the liquidation of an obligation imposed by law apart from any promise or agreement. In the Harris case the reason the transfer was not taxable was not because it was made pursuant to a judicial decree, but because it was made to settle an obligation which arose apart from any promise or agreement. If the settlement in the Harris case had been made to satisfy a judicial decree, which instead of creating the obligation for the transfer had simply given sanction to a pre-existing obligation created by contract, it would have been taxable. This is the point of the Hooker case. It is a necessary inference from the Harris case, otherwise it would be possible to make transfers which would escape the gift tax by contractual arrangements whieh were legally enforceable, but were not founded upon adequate and full consideration. If, for example, the controlling consideration in determining whether there is a transfer taxable under the gift tax was whether the transfer was made pursuant to a judicial decree, regardless of the source of the obligation upon which the decree was predicated, it would be possible for a man to promise to pay another a million dollars by an instrument under seal, in a juridiction where seals retain their common law vitality, and effect a tax-free transfer by having the transferee reduce this obligation to judgment before the transfer was made.

On the other hand, presumably if a divorce court has no power other than to approve a divorce settlement in order that the settlement may, in the future, have one more sanetion-contempt under the divorce court-, then, any transfer made pursuant to that settlement would be taxable as a gift because the limited power of the court would not be sufficient to create an obligation for the transfer.

\footnotetext{
25 "Liabilities imposed by law or arising out of torts are deductible" from the gross estate to arrive at net estate, and since this regulation is usod in connection with $\$ 812$ of the $I$. $R$. C., part of which has been read into tho gift tax, apparently the same would apply under $\$ 1002$ of the gift tax. TrEas. RDg. 105, \$ 81.36 .
} 


\section{Conclusion}

Even though the Harris case reached a desirable result on its facts, the implication from the decision that voluntary divorce settlements are taxable as gifts unless based upon adequate and full consideration seems unfortunate. The weakriess of the case is that it lays down a distinction based on form rather than on substance. Moreover, it will tend to discourage voluntary and amicable settlements and encourage property litigation in divorce cases.

In view of the present allowance of marital deductions under both the estate and gift taxes, ${ }^{26}$ it would seem that some provision should be made for tax-free divorce settlements. If the parties can come to some amicable settlement without taking that part of their grievance to the court, why not permit it and at the same time provide for tax-free transfers under such conditions? There is at least a moral obligation for the parties to make some proper settlement of their property interests, and there seems to be no sound basis for saying that only when a court decree creates an obligation for the settlement will a transfer in satisfaction thereof be tax-free. ${ }^{27}$

2026 USCA $\$ 1004 . " 6 * * *$ In computing net gifts for the calendar year 1943 and subsequent calendar years, there shall be allowed as deductions: (a) Residents-In the case of a citizen or resident- *** (3) Gift to Spouse.In General.-Where the donor transfers during the calendar year (and after the date of the enactment of the Revenue Act of 1948) by gift an interest in property to a donee who at the time of the gift is the donor's spouse-an amount with respect to such interest equal to one-half of its value."

26 USCA $\$ 812$. "For the purpose of the tax the value of the net estate shall be determined, in the case of the citizen or resident of the United States by deducting from the value of the gross estate-*** (e) Bequests Etc., to Surviving Spouse.-(1) Allowance of Marital deduction.-(A) In General-An amount equal to the value of any interest in property which passes or has passed from the decedent to his surviving spouse, but only to the extent that such interest is included in determining the value of the gross estate. *** (H) Limitation on aggregate of deductions.-The aggregate amount of the deductions allowed under this paragraph (computed withont regard to this subparagraph) shall not exceed 50 per centum of the value of the adjusted gross estate, ...'

27 "On any legislative revisitation of this area some recognition should be given to the fact that a husband. may now leave half his property to his wife free from estate tax. In light of the auxiliary role of the gift tax there is surely little reason now for imposing any $\operatorname{tax}$ on the acceleration of the wife's inheritance by divorce when that inheritance would pass tax free at death in the absence of divorce. The failure to provide some sort of divorce marital deductions to parallel the non-taxability of the division of the community property on divorce can only be explained by legislative oversight." Pedrick, op. cit., supra note 11, at p. 195. 
Although the Harris case seems to preclude any distinction between ante-nuptial and post-nuptial settlements, it seems clear that there is usually a complete absence of any donative intent in connection with divorce settlements. Perhaps, the happiest solution for transfers in connection with a divorce would be to analogize them to bona fide business transactions, which are not treated as taxable gifts regardless of adequacy of consideration. ${ }^{28}$

Id. at 189. "While reason argues against any distinction based on the incorporation or non-incorporation of the [property settlement agreement into the decree of divorce] . . . , prudence will lead many to incorporate until some bolder soul has taken the chance" that the court will hold the same whether the agreement is incorporated into the decree or not.

${ }_{28}$ TREAS. REA. 108, 86.8, provides, in part: "[A] sale, exchange, or other transfer of property made in the ordinary course of business (a trangaction which is bona fide, at arm's length, and free from any donative intent), will bo considered as made for an adequate and full consideration in money or money's worth."

In Harris $v$. Commissioner, supra note 11, the court said at p. 112: "This transaction is not 'in the ordinary course of business' in any conventional sense. Few transactions between husband and wife ever would be; and those under the aegis of a divorce court are not. But if two partners on dissolution of the firm entered into a transaction of this character or if chancery did it for them, there would seem to be no doubt that the unserambling of the business interests would satisfy the spirit of the Regulations. No reason is apparent why husband and wife should be under a heavier handicap absent a statute which brings all marital property settlements under the gift tax." 